Dziawgo, T. (2018). Wealth management market in China. Opportunities and challenges. Copernican Journal of Finance \& Accounting, 7(4), 47-57. http://dx.doi.org/10.12775/CJFA.2018.019

\author{
TOMASZ DzIAWgo* \\ Warsaw School of Economics
}

\title{
WEALTH MANAGEMENT MARKET IN CHINA OPPORTUNITIES AND CHALLENGES
}

Keywords: private banking, wealth management, ultra high-net worth individuals, high-net worth individuals.

J E L Classification: D31, G21, 016.

\begin{abstract}
As the key player in prospective Asia-Pacific market, China is becoming one of the most notable countries with regard to private banking services. In spite of being relatively young, Chinese wealth management market has been developing rapidly with increasing number of affluent clients and their value of total assets. Currently undergoing through transition between early development and maturity, Chinese wealth management market has several challenges to face in order to become a fully established one. The research objective of the article is to present the characteristics and potential of Chinese wealth management market and to what extent does it correspond with global wealth management trends. The research method applied in the paper is an in-depth analysis of the case study regarding Chinese wealth management market with its' potential and challenges. In order to carry out the analysis, various reports on the issue in question published by leading consulting companies, banks and experts were analyzed and relevant statistical data in the given period of time was examined as well. The outcome of the article is to list key steps for Chinese wealth management market to be taken, in order to elevate its' status as one of the leading wealth management markets worldwide.
\end{abstract}

Date of submission: February 18, 2019; date of acceptance: March 29, 2019.

* Contact information: tomasz.dziawgo@gmail.com, Warsaw School of Economics, Al. Niepodległości 162, 02-554 Warszawa, Poland, phone: +48 668145 140; ORCID ID: https://orcid.org/0000-0001-5910-8997. 


\section{INTRODUCTION}

In every business sector what matters is not only number of clients, but also their type. Banking sector is no different - it has not only retail and corporate clients, but also wealthy individuals that may be offered additional and exclusive services (Loury, 2008, pp. 25-26). These services are provided within private banking sector that treats each affluent client with tailor-made approach (Shen \& Cannella, 2003, pp. 2-4). It distinguishes itself from other banking divisions by for instance, offering exclusive investment advisory with special regard to client's portfolio of assets and risk profile, unique services in wealth preservation, wealth inheritance, legal and tax consultations or planning strategic decisions for family business (Hsiu, 2017, pp. 6-8). These wealthy clients that private banking services are dedicated for, are named High-Net Worth Individuals (HNWI) and have assets with total value estimated at least 1 million USD (Dziawgo, 2006, pp. 20-22). Among HNWI we can also distinguish Ultra High-Net Worth Individuals (UHNWI) with total assets exceeding 50 million USD in value. Targeting those people may significantly boost brand recognition of the bank, improve corporate image and provide long-term reliable clients, who along with their relatives have potential to cooperate with one bank even in future generations.

Number of HNWI and UHNWI has been constantly increasing worldwide, with Asia-Pacific region having the most notable growth (EY, 2014). Only in 2017, the region was responsible for creating over $40 \%$ of the new HNWI wealth in the entire world. One of the key upcoming countries with regard to affluent individuals and wealth management is China. While the population of HNWI within 2010-2017 was growing 8.8\% year-on-year in the region, China was enjoying over $11.2 \%$ increase within the same period of time. The similar trend has been ongoing with the amount of wealth of those individuals. While Asia-Pacific region within 2010-2017 had a growth of 9.7\%, China has been above the region average having $11.8 \%$ in the same period of time (Capgemini, 2018). What is more, China's HNWI population grew by $11.2 \%$ and HNWI's wealth increased by $12.5 \%$ in 2017 , compared to $9.1 \%$ and $9.8 \%$ respectively in 2016 therefore depicting upward trend for wealth management market development (Capgemini, 2018). China therefore becomes significantly more important country in the region in wealth management, which can be shown in tables 1 and 2. 
Wealth management market in China...

Table 1. HNWI population in Asia Pacific Region and China within 2010-2017

\begin{tabular}{|c|c|c|c|}
\hline \hline \multirow{2}{*}{} & \multicolumn{3}{|c|}{ HNWI population (millions) } \\
\cline { 2 - 4 } & Asia-Pacific Region & China & China's total share \\
\hline \hline 2010 & 3.3 & 0.53 & $\sim 16 \%$ \\
\hline 2013 & 4.3 & 0.76 & $\sim 17.5 \%$ \\
\hline 2017 & 6.2 & 1.26 & $\sim 20 \%$ \\
\hline \hline
\end{tabular}

S o u r c e : Capgemini Asia-Pacific Wealth Report, 2018.

Table 2. HNWI wealth in Asia Pacific Region and China within 2010-2017

\begin{tabular}{|c|c|c|c|}
\hline \hline \multirow{2}{*}{} & \multicolumn{3}{|c|}{ HNWI wealth (trillions USD) } \\
\cline { 2 - 4 } & Asia-Pacific Region & China & China's total share \\
\hline \hline 2010 & 10.8 & 2.66 & $\sim 25 \%$ \\
\hline 2013 & 14.2 & 3.77 & $\sim 26.5 \%$ \\
\hline 2017 & 21.6 & 6.46 & $\sim 30 \%$ \\
\hline \hline
\end{tabular}

S o u r c e : Capgemini Asia-Pacific Wealth Report, 2018.

Considering 10 countries with the most HNWI individuals, China had the highest increase of such individuals from 2016 to 2017, accounting for 11\%. The comparison between HNWI population and its' 2016-2017 year increase, is presented in table 3. What is more, top 4 presented countries (USA, Japan, Germany, China) account for over $61 \%$ of HNWI population worldwide.

Table 3. Largest HNWI population by country with 2016-2017 increase

\begin{tabular}{|l|c|c|}
\hline \hline \multicolumn{1}{|c|}{ Country } & HNWI Population (million) & 2016-2017 increase (\%) \\
\hline \hline USA & 5.29 & 9 \\
\hline Japan & 3.16 & 7 \\
\hline Germany & 1.37 & 11 \\
\hline China & 1.26 & 9 \\
\hline France & 0.63 & 1 \\
\hline United Kingdom & 0.58 & 7 \\
\hline Switzerland & 0.39 & 7 \\
\hline
\end{tabular}


Table 3. Largest HNWI population...

\begin{tabular}{|l|c|c|}
\hline \hline \multicolumn{1}{|c|}{ Country } & HNWI Population (million) & 2016-2017 increase (\%) \\
\hline \hline Canada & 0.38 & 6 \\
\hline Australia & 0.28 & 9 \\
\hline Italy & 0.27 & 9 \\
\hline \hline
\end{tabular}

S o u r c e : Capgemini Asia-Pacific Wealth Report, 2018.

Total number of millionaires in China is supposed to grow by $62 \%$ within 5 years (2018-2023), which is significantly faster than in most developed economies, such as: Germany (41\%), Switzerland (36\%) United Kingdom (30\%) or USA (18\%), with the world's average being $36 \%$ growth within this period of time (Credit Suisse, 2018, p. 41). From the beginning of XXI century, China's total wealth skyrocketed from 3.7 trillion USD to 51.9 trillion USD, thus increasing 14 times in 18 years with an annual growth of 15\%. With China's HNWI population and HNWI wealth increasing, it only depicts how much potential lies in private banking in China that could benefit both parties.

\section{THE RESEARCH METHODOLOGY AND THE COURSE OF THE RESEARCH PROCESS}

For the purpose of this paper, the case study of Chinese wealth management market has been developed through critical analysis of literature, reports issued by leading financial institutions, statistical data concerning both wealth and population of analyzed HNWI (High Net-Worth Individuals) and UHNWI (Ultra High Net-Worth Individuals). Content analysis was aimed at identifying and describing ongoing trends both on the Chinese wealth management market and worldwide to predict the direction in which the Chinese market would follow. Then, the main challenges for the Chinese market were specified and possible solutions were given on the basis of western markets analysis. Furthermore, literature used in this paper helped to understand fundamental concepts behind wealth management and private banking. Lastly, statistical data played a key role to understand the fast growth and underlying potential of the Chinese wealth management market and a key part in driving final conclusions. 


\section{CHINESE WEALTH MANAGEMENT MARKET CHARACTERISTICS AND TRENDS}

Chinese wealth management market has been on the rise since 2007 when first commercial banks introduced initial private banking services. Because of rapidly growing Chinese economy and ongoing internationalization of Chinese companies, within just a decade China has become one of the most important wealth management market in the world. It can be seen especially in recent years. For instance number of UNHWI people increased from 110 thousand to approximately 300 thousand within 2011 and 2016. Interestingly enough, a significant number of UHNWI clients ( 25\%) are not businessmen or investors, but rather professionals such as doctors and lawyers, who became affluent not by making investments but through performing their profession for certain amount of time. In spite of that, business owners and representatives of finance industry have the strongest foothold among existing UNHWI and HNWI people. These various sources of gaining wealth however, shapes Chinese wealth management market to be more diversified (BCG, 2017).

One of the most crucial trends on the Chinese market is the rapidly increasing importance of the second generation. Since it is relatively young, it has not yet experienced several issues of matured wealth management markets such as distributing wealth among family's next generations. Figure 1 proves that it becomes one of the most important priorities, as significantly more UHNWI and HNWI are more concerned about wealth preservation, inheritance of wealth and education of next generation rather than wealth creation itself.

Figure 1. Priorities among UHNWI and HNWI within 2009-2017

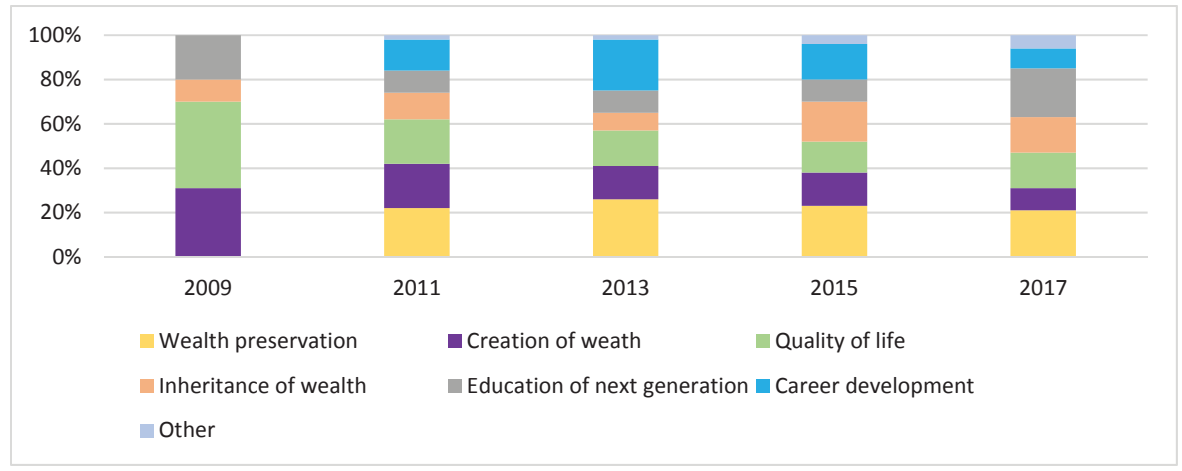

S o u r c e : Bain \& Company and China Merchants Bank China Private Wealth Report. 
As increasingly new successors enter the UNHWI and HNWI market, the demand for new wealth management services arises as well. First generation understands that inheritance is a key factor in setting up the optimal shareholder structure of family business among existing family members. Top-notch quality of this service may become a decisive factor between choosing bank A or bank $\mathrm{B}$ as a future partner.

Wealth management has been undergoing through heavy digitalization trend worldwide. Not only do the companies want to stay ahead from other market players through numerous innovations with the usage of blockchain, big data, social media or advanced analytics (SS\&C, 2018). One of the most notable solutions however, is robo-advisory, in which the advanced program using machine learning and artificial intelligence propose tailor-made solutions for client considering the risk profile, preferable duration of investment or desired market (Dziawgo, 2018, p. 77). Robo-advisory is predicted to manage assets of total value 1 trillion USD worldwide until 2020 (Forbes, 2018). Although, Chinese UNHWI and HNWI appreciate the convenience and are certainly becoming increasingly more open to such solutions in less crucial areas like performance feedback, they would still rather have a direct meeting with a bank representative in most cases. Services like conducting investment strategy, legal and tax advisory or even family business perspectives are rather to be discussed face-to-face (Bain, 2017, p. 15).

One of the most notable signs that China's wealth management market is developing is increased number of overseas assets in portfolio of shares. Figure 2 depicts share of overseas assets to overall assets of HNWI.

HNWI invest increasingly more overseas with close to $30 \%$ of their total assets being outside of China, while in 2008 overseas assets constituted for less than $10 \%$ of total assets. The most important reasons for Chinese HNWI to invest overseas are portfolio diversification and discovering new market opportunities abroad. It is also worth to note that less than $20 \%$ of HNWI invested overseas in 2011, while over 50\% of HNWI invest outside of China as of 2017. This trend of increasing overseas share in overall assets depicts that Chinese wealth management market is developing. 
Figure 2. Share of HNWI overseas assets in relation to domestic assets

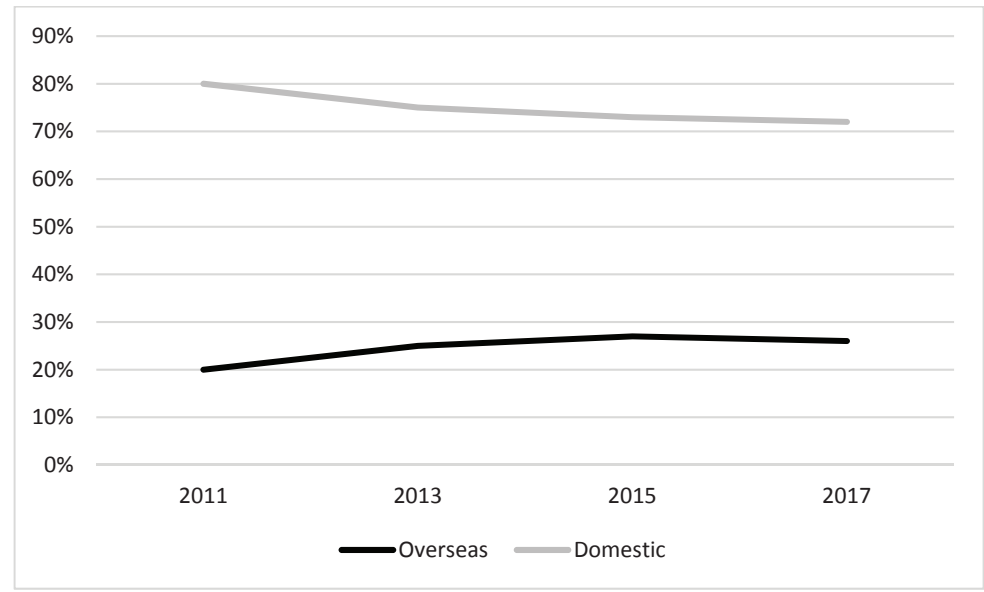

S o u r c e : Bain \& Company and China Merchants Bank China Private Wealth Report.

What makes Chinese Wealth Management market even more interesting are important regulatory changes encouraging foreign market players to enter the Chinese market. China allowed to increase the maximum stake of shares of foreign entity from $49 \%$ to $51 \%$, which could be raised up even to $100 \%$ (Deloitte, 2018). The first bank having the majority in stake of shares in China was UBS - it currently has $51 \%$ of shares in local securities operations (Financial Times, 2018). Also, Private Fund Management (PFM) license resulted in higher activity from foreign managers to establish $100 \%$ owned entity on the Chinese territory. These changes would definitely result in opening up the domestic wealth management market (McKinsey, 2018).

\section{Chinese WEALTh MANAGEMENT MARKET CHALLENGES}

Although Chinese wealth management market is developing rapidly, it has challenges that are needed to be faced. The most crucial one seems to be the uncertainty. The market, compared to its' European and American counterparts is young and banks have a difficult task to develop their services at the same pace as the market growth. Considering that market develops very quickly, this seems to be both a difficult task. However if bank is capable of meeting the cli- 
ent's needs and expectations through innovative and tailor-made approach in this uncharted territory, it can win a valuable client for generations to come.

In order to gain a UNHWI and HNWI clients trust, it is essential for bank to develop and maintain a long-term relationship. This may be a challenge on the Chinese wealth management market, due to the fact that the majority of wealthy individuals are self-made businessmen with high degree of confidence both in their instinct and decision making. They may be of the opinion they do not need neither financial advisor nor his services, because they are fully capable of managing their fortune by themselves (Capgemini, 2018).

What is more, low-risk investable assets offering above-market returns are increasingly harder to spot. This might be an issue to overcome, due to highspeed wealth accumulation desire along with high return expectations from UHNWI and HNWI. Shortage of these assets may serve as an opportunity for the bank, that could be able to find latest investment opportunities significantly faster than a wealthy person. Also, the value of advice from the bank representative may increase with clients having more realistic approach to returnrates.

Furthermore, the role of exceptional Customer Experience (CX) is becoming increasingly more crucial. Behind quality of financial advisory services, it is considered to be the most important factor for clients to choose a company. According to KPMG, the six key elements of CX strategy are:

- personalization - providing tailor-made services for each client considering the risk profile, investment goals etc.,

- integrity - maintaining trust and reliability,

- expectations - meeting and exceeding client's expectations,

- time and effort - providing client with relevant information as fast as possible with minimizing client's effort to obtain them,

- resolution - avoiding poor experience and resolving it quickly in case of happening,

- empathy - understanding the client with special regard to his priorities and worries.

With that being said, the key issue for wealth management companies in CX is how to track customer satisfaction on the regular basis. This is a key challenge, which causes companies to stay innovative and develop digital solutions. It is essential for Chinese wealth management companies to consider Customer Experience in their strategy and develop a method to track the overall satisfaction of clients (KPMG, 2018, pp. 15-17). 
Lastly, considering both wealth inheritance on a large scale in China and heavy impact of new technologies in wealth management market worldwide, there are increased security concerns and fear of data leakages (BNP Paribas, 2018). Due to the fact that wealth management companies have huge quantities of sensitive data of wealthy individuals, the risk of data theft is increased and it can lead to both financial loss for the client and loss of trust for the company. Latest innovative solutions and new digital services may not be fully prepared for cyber-attacks, therefore leaving them exposed as a potential target for an attack. According to Capgemini, estimated losses from cyber crimes are expected to amount to 6 trillion USD worldwide, which should definitely be considered while establishing a developed Chinese wealth management market. Therefore necessary steps from wealth management companies for cybersecurity need to be taken, such as increasing IT security expenditure or developing tailored safety procedures.

\section{THE OUTCOME OF THE RESEARCH PROCESS AND CONCLUSIONS}

The most important conclusion for banks present in Chinese wealth management market is to establish and sustain client loyalty. There is no doubt that UNHWI and HNWI are unique type of clients and their retention may provide banks with reliable clients even for generations, which is hardly the case for retail clients (Baker \& Chiu, 2017, pp. 410-412). Knowing that banks should correspond to the most urgent needs on the market, they ought to switch their attention from wealth creation services to wealth inheritance and wealth preservation (Jacobides \& Winter, 2012, pp. 5-6). These services, if carried out properly, can sustain wealthy clients with the second generation entering the UNHWI and HNWI market (EY, 2018, p. 10).

Moreover, banks should definitely consider applying latest innovative solutions on the Chinese wealth management market as well. There is little to no doubt that increasingly more affluent clients would value convenience and comfort in private banking services. However, banks should implement new ideas with regard to Chinese market specifics. It is unknown to what degree would several solutions appeal to Chinese clients, considering the fact that they still consider face-to-face meetings as the main approach of performing private banking services (Accenture, 2016, p. 4).

With UNHWI and HNWI client retention as a key, banks should carry out a long-term, possibly life-long strategy tailor-made for every individual client. 
While doing so, it is of the utmost importance for the bank to ensure highest possible degree of customer experience. Increasingly more clients are becoming convinced to use social media like WeChat, mobile applications and several others digital and automated channels to enhance satisfaction of clients, maintaining strong relationships with them in the process.

Chinese wealth management market is not only one of the biggest wealth management markets in the world, but also the one with a lot of potential to grow. This combination does not occur often, which is the main reason behind the uniqueness of the Chinese market. For service providers, adapting seems to be difficult, due to the fact they need to develop at least as fast as the market itself in order to stay competitive. However, if they manage to do so, they can gain a strong foothold on a one of a kind market.

\section{REFERENCES}

Accenture (2016). The future of wealth management, http://www.accenture.com/plen/insight-future-wealth-management (accessed: 05.02.2019).

Bain \& Company and China Merchants Bank China Private Wealth Report, http://www. bain.cn (accessed: 02.02.2019).

Baker, R., \& Chiu, I. (2017). Corporate Governance and Investment Management. Cheltenham: Edward Elgar Publishing.

BCG (2017). Boston Consulting Group and China Industrial Bank Private Banking China Wealth 2017: The way ahead after a golden decade, http://image-src.bcg.com/Images/BCG_China-Wealth-2017_ENG_Dec-2017_ (accessed: 01.02.2019).

BNP Paribas (2018). Winds of Change: The Future of Fintech in the Wealth Management Industry, https://wealthmanagement.bnpparibas/asia/en/expert-voices/fintechtrends-in-wealth-management.html (accessed: 05.02.2019).

Capgemini (2018). Capgemini Top Trends in Wealth Management 2018, https://www. capgemini.com/wp-content/uploads/2017/12/wealth-managment-trends-2018 (accessed: 01.02.2019).

Capgemini Asia-Pacific Wealth Report 2018. https://www.capgemini.com/wp-content/uploads/2018/11/Report_APWR-2018 (accessed: 01.02.2019).

Credit Suisse (2018). Global Wealth Report 2018: US and China in the lead, http://www. credit-suisse.com/corporate/en/articles/news-and-expertise/global-wealth-report2018-us-and-china-in-the-lead-201810.html (accessed: 07.02.2019).

Deloitte (2018). 2019 Investment Management Industry Outlook, http://www2.deloitte. com/us/en/pages/financial-services/articles/investment-management-industry-outlook.html (accessed: 05.02.2019).

Dziawgo, L. (2006). Private Banking. Bankowość dla Zamożnych klientów. (Private Banking. Banking for affluent clients.) Warsaw: Wolters Kluwer. 
Dziawgo, T. (2018). Roboadvisory redefiniuje doradztwo finansowe. (Roboadvisory redefines financial advisory.) In M. Broniewska, J. Czerwińska (Eds.). Co zmienilibyśmy w Polsce i Europie? (What would we change in Poland and Europe?) Gdańsk: European Financial Congress Academy.

EY (2014).EY Rethinking private banking in Asia-Pacific,http://www.ey.com/Publication/ vwLUAssets/Rethinking_private_banking_in_Asia-Pacific (accessed: 02.02.2019).

EY (2018). EY Wealth management outlook - 2018, http://www.ey.com/Publication/ vwLUAssets/ey-wealth-management-outlook-2018/\$file/ey-wealth-management-outlook-2018 (accessed: 04.02.2019).

Financial Times (2018). UBS to take majority stake in China joint venture, http://www. ft.com/content/0381d6be-f542-11e8-af46-2022a0b02a6c (accessed: 06.02.2019).

Forbes (2018). Five predictions on the future wealth management, http://www. forbes.com/sites/forbesfinancecouncil/2018/05/15/five-predictions-on-the-future-of-wealth-management/\#12189f2b3c6d (accessed: 04.02.2019).

Hsiu, T. (2017). Factors affecting Wealth Management Services: From investors' and advisors' perspectives. The Journal of Wealth Management, 20(1), 17-29. https://dx. doi.org/10.3905/jwm.2017.20.1.017.

Jacobides, M., \& Winter, S. (2012). The dynamics of wealth, profit, and sustainable advantage. Strategic Management Journal, 33(12), 1384-1410. https://dxdoi.org/10.1002/ smj.1985.

KPMG (2018). How customer experience is shaping the future of wealth management, http://home.kpmg/au/en/home/insights/2018/06/refocus-on-the-customer.html (accessed: 04.02.2018).

Loury, K. (2008). Wealth Management: Using the Balance Sheet Methodology. The Journal of Wealth Management, 11(2) 19-28. https://dx.doi.org/10.3905/jwm.11.2.19.

McKinsey (2018). Will the good times keep rolling for Asia's asset managers? https:// www.mckinsey.com/ /media/McKinsey (accessed: 05.02.2019).

Shen, W., \& Cannella, Jr.A. (2003). Will succession planning increase shareholder wealth? Evidence from investor reactions to relay CEO successions. Strategic Management Journal, 24(2), 191-198. https://dx.doi.org/10.1002/smj.280.

SS\&C (2018). Opportunities and challenges facing private banks in APAC, http://www. ssctech.com/blog/opportunities-and-challenges-facing-private-banks-in-apac (accessed: 4.02.2019). 